\title{
The Effect Of Domperidone Toward Breast Milk Production On Sectio Caesarea Mother
}

\author{
Sri Dinengsih, Cholisah Suralaga \\ Midwifery Study Program, Faculty of Health Sciences, National University of Indonesia \\ Jalan Margonda Raya, Pondok Cina, Kecamatan Beji, Kota Depok, Jawa Barat \\ E-mail: sridinengsih@civitas.unas.ac.id
}

\begin{abstract}
Abstrak
Ibu yang melahirkan dengan operasi caesar (SC) seringkali mengalami kesulitan untuk mendapatkan produksi ASI yang memadai. Berbagai upaya telah dilakukan untuk mengatasi masalah tersebut, termasuk intervensi farmakologis. Salah satu obat yang mungkin digunakan adalah domperidon. Domperidon merupakan reseptor antagonis dopamin perifer yang bekerja dengan cara menghambat efek penghambatan sekresi prolaktin yang difasilitasi oleh dopamin untuk meningkatkan produksi ASI. Penelitian ini bertujuan untuk mengungkap pengaruh domperidon terhadap produksi ASI pada ibu melahirkan dengan SC di Indonesia. Penelitian ini merupakan penelitian eksperimen semu dengan desain two group post test only. Sampel dalam penelitian ini adalah 30 pasien post sectio caesarea yang terdiri dari 15 pasien kelompok intervensi dan 15 pasien kelompok kontrol. Pengambilan sampel dilakukan dengan purposive sampling. Instrumen yang digunakan adalah lembar observasi. Analisis hasil dilakukan dengan menghitung distribusi frekuensi dan analisis bivariat dengan uji Mann Whitney. Rata-rata skor produksi ASI pada ibu pasca SC pada kelompok intervensi adalah 22,60, sedangkan skor rata-rata produksi ASI pada ibu post SC pada kelompok kontrol adalah 15,47, Asymp. nilai Sig (2 tailed) $0,020(0,020<0,05)$. Domperidone telah disetujui memiliki pengaruh yang signifikan untuk meningkatkan produksi ASI pada ibu pasca SC. Peningkatan produksi ASI dapat dilakukan secara non-farmakologis, tetapi terapi farmakologis juga dapat dipertimbangkan jika terapi nonfarmakologis tidak bekerja dengan baik dalam meningkatkan produksi ASI.
\end{abstract}

Kata kunci: domperidone; produksi asi; sectio caesari

Mothers that give birth with section caesaria (SC) often experience difficulty to get a adequate breast milk production. Various kinds of effort have been conducted to overcome this problem, including pharmacological intervention. One of the medicines that could be possibly used is domperidon. Domperidon is an antagonist receptor of peripheral dopamine that works by choking inhibition effect of prolactin secretion facilitated by dopamine to improve breast milk production. The research aimed to unveil the effect of domperidon toward breast milk production on mother that give birth with SC in Indonesia. This is a quasi-experiment research with two groups post-test only design. The sample of this research 30 were post sectio caesarea patients consisting of 15 patients in intervention group and 15 patients in control group. Purposive sampling was used in the research to get the samples. The instrument used was observation sheets. Result analysis was conducted by calculating the frequency distribution and bivariate analysis with Mann Whitney test. The average score of breast milk production among post-SC mother in the intervention group was 22,60, while the average score of breast milk production among post-SC mother in control group was 15,47, Asymp. value Sig (2 tailed) 0,020 (0,020 < 0,05). Domperidone has been approved to have a significant effect to improve breast milk 
production on post-SC mothers. Improving breast milk production could be conducted non-pharmacologically, but pharmacological therapy could also be considered if the nonpharmacological therapy doesn't work well in improving breast milk production.

Keywords: domperidone; production breast milk; sectio caesar

Article info:

Article submitted on November 12, 2020

Articles revised on December 02, 2020

Articles received on December 28, 2020

DOI: $h$ ttp://dx.doi.org/10.21927/jnki.2020.8(4).286-291

\section{INTRODUCTION}

Breast milk production is a process of releasing oxytocin hormone to floe breast milk produced within breast. The problem of early releasing breast milk could happen to mothers who experience sectio caesaria; it could result in bad impact toward the infant because new born baby needs colostrum. Post-SC mothers will face difficulty in early breastfeeding initiation because of rooming-in factor, SC wound, and weakness because of anesthesia, therefore post-SC patient could do breastfeeding her infant several hours after labor (1).

WHO recommends that newborns should receive exclusive breastfeeding for six months because breast milk is the best natural nutrition for babies with the most suitable nutritional content for optimal growth (2). UNICEF confirms that formula-fed babies have a 25 times higher chance of dying in the first month of birth and formula-fed babies are 25 times higher than babies who are exclusively breastfed (3).

The coverage of exclusive breastfeeding in Indonesia is still low, namely $37.3 \%$ of babies in Indonesia who are exclusively breastfed. It means that there are 2/3 of babies in Indonesia who are not breastfed exclusively. In Indonesia, the number of SC births is high. According to national survey data 2018 there were around $28.9 \%$ of all deliveries (4).

Mothers with SC will experience anesthesia and postoperative pain so they are not free to breastfeed their babies intensely. Besides, after surgery mother must be moved to the Recovery Room. Although, currently, implementing early breastfeeding initiation (IMD) can also be done in the operating room, not all hospitals have the same policy. In addition, the feeling of the mother who is not sure that she can give breast milk to her baby because of the condition will cause a decrease in oxytocin so the milk cannot come out immediately after giving birth and finally the mother decides to give formula milk(5).

Domperidone is known to be used as a breast milk booster among nursing mothers. IDAI stated that domperidone used as a lactogogue (a substance that can be trusted to increase milk production) was first reported in 1983. This substance increases prolactin serum in lactating women. Side effects of domperidone are very rare, including dry mouth, headache (relieves with reduced dose) and stomach cramps. Longterm high-dose domperidone treatment in mice was associated with an increase in the number of breast tumors. This has never been reported in humans (6).

In Asia and Europe, domperidone has long been used as a prokinetics and antiemetic. The clinical use of domperidone is in the treatment of gastroesophageal reflux disease, diabetic gastroparesys, chronic dyspepsia, and is sometimes recommended to stimulate postpartum lactation. Domperidone is the most recommended medicine because it has been 
proven effective, it has no side effects on the baby, and rare side effects in breastfeeding mothers. In addition, based on the literature, domperidone, as a galactogogue, has been widely used in various countries even though it is off label ", such as Australia, the Netherlands, Belgium, England, Ireland, Italy, Japan and Canada (7).

Domperidone is preferred over other drugs to increase milk production because it does not cross the blood brain barrier. Domperidone is a peripheral dopamine receptor antagonist, works by inhibiting the inhibitory effect of dopaminemediated prolactin secretion, so that milk production increases (8).

For mothers whose milk production decreases and does not respond to nonpharmacological therapy, the use of galactogogues is often considered. Galactogogues are substances that are assumed to aid in the initiation, continuation or augmentation of breast milk production. They include pharmaceutical agents and herbal supplements. Recently, the Cochrane Collaboration published a review of pharmaceutical galactogogues given to mothers of hospitalized premature babies. Two domperidone trials met the review criteria, and the meta-analysis showed modest increases in expressed milk volume of $99.49 \mathrm{~mL} /$ day $(95 \%$ confidence interval [Cl], -1.94-201) in mothers of preterm infants who were given domperidone (9).

On a research of cross clinical design random double test in Australia toward 6 mothers of premature babies that gat domperidon 30 $\mathrm{mg} /$ day and $60 \mathrm{mg} / \mathrm{day}, 2 / 3$ samples showed the improvement of breast milk production and significant prolactin serum. The improvement of breast milk production among the samples is shown on the increase of dosage from 30 $\mathrm{mg}$ became $60 \mathrm{mg}$, even though the amount of domperidon within breast milk is very small and the risk toward babies is minimal (6).

Some researchers began to see other benefit of domperidone, as galactogogue. The recent research proves that the medicine was effective to improve breast milk production as the choker of dopamine receptor. Besides domperidone, there are some medicines that have an effect to stimulate lactation (galactogogue), such as metoclopramide, chlorpromazine, sulpiride, oxytocin hormone and growth hormone (10).

Harapan Jayakarta Hospital is a type C hospital that accept reference from private midwifery clinic to do sectio caesaria SC based one medical indication, in 2018 the number of SC was 125 cases, on average 10-12 cases per month; from the previous studies conducted by a researchers toward 10 post-SC mothers, 5 of them don't produce and release breast milk on the third day of the birth. Thus, the researchers were interested to do a research entitled "The Effect of Domperidone toward Breast Milk Production on Post-SC mother in Harapan Jayakarta Hospital Jakarta.

\section{MATERIALS AND METHODS}

This research is a quasi-experimental using two group post-test only design. The design of this research used two subjects, intervention group and control group. The intervention group as a group of post-SC mother that consume domperidone tablet $10 \mathrm{mg} 3$ times for 5 day's, while control group do not consume domperidone. The samples taken for this research were 30 post-SC mothers using purposive sampling. The inclusion criteria of the research were post-SC mother day 1 to 5 day, having no allergic history with domperidone and willing to be respondents. The research was conducted in Harapan Jayakarta Hospital from April to June 2019. The independent variable of the research is the treatment of Domperidone while the dependent variable is breast milk production. The instruments of this research was observation sheet and electric pump to store breast milk among post-SC mother on intervention group and control group. Before 
the treatment explanation was given to the respondents through informed consent.

This research has got a permission from Harapan Jayakarta Hospital, a letter No. 003/ADSDM/RSHJ/III/2019. Data that have been collected were processed through editing, coding, processing and cleaning. The normality test used Shapiro Wilk method (a low number of sample $\leq 30$ samples). It is found the significance result in intervention group 0,000 and in control group 0,000. The significance value is $<0,05$ which means that the data of breast milk production were not distributed normally. Because the data were not distributed normally the test that would be conducted was non-parametric test. Univariate analysis was done to see the distribution of the characteristics of pos-SC mothers such as, age, education, parity, and occupation. Numeric data, age, were presented in the form of central tendency distribution Mean, median, minimum and maximum value. Categorical data were presented by calculating frequency distribution and percentage. Bivariate analysis was conducted toward two variables to unveil the relation between domperidone and breast milk production. Test used in the research was Mann Whitney test and Rank Spearman test.

\section{RESULT AND DISCUSSION}

Based on Table 1, it shows that from 15 respondents of post-SC mothers in the intervention group, the mean of breast milk production is 22,60 with deviation standard 6,905; the minimal amount is $7 \mathrm{~mL}$ and the maximal amount is $32 \mathrm{~mL}$. From the interval estimation, it could be concluded that $95 \%$ is convinced that the breast milk production is between 18,7826,42 . While from 15 respondents of post-SC mothers on the control group, the mean of breast milk production is 15,47 , with deviation standard 8,855 ; the minimal amount is $2 \mathrm{~mL}$ and the maximal amount is $30 \mathrm{~mL}$. From the estimation
Table 1. the average of breast milk production on Post SC mother Intervention and Control group in Harapan Jayakarta Hospital 2019

\begin{tabular}{|c|c|c|c|c|c|}
\hline $\begin{array}{l}\text { Breast milk } \\
\text { Production }\end{array}$ & $\mathbf{N}$ & Mean & S.D & $\begin{array}{l}\text { Min- } \\
\text { Max }\end{array}$ & $95 \% \mathrm{Cl}$ \\
\hline \multicolumn{6}{|l|}{ Intervention } \\
\hline Group & 15 & 22,60 & 6,905 & $7-32$ & $18,78-26,42$ \\
\hline \multicolumn{6}{|l|}{ Control } \\
\hline Group & 15 & 15,47 & 8,855 & $2-30$ & $10,56-20,37$ \\
\hline
\end{tabular}

of the interval, it could be concluded that 95\% is convinced that the breast milk production is between 10,56 - 20,37.

Based on Table 2, the result of Mann Whitney test shows that the rank of breast milk production average on the intervention group is 19,00 and on the control group is 12,00 . There is difference of average rank between intervention and control group. The value of Asymp. Sig. (2-tailed) is $0,029(0,029<0,05)$. It proves that the difference of the average rank between the two groups means statistically or significantly.

Table 2. Difference Test of Breast Milk production toward post-SC Mother in Intervention and Control Group

\begin{tabular}{clcc}
\hline $\begin{array}{c}\text { Breast Milk } \\
\text { Production }\end{array}$ & \multicolumn{1}{c}{ Group } & $\begin{array}{c}\text { Mean } \\
\text { Rank }\end{array}$ & $\begin{array}{c}\text { Asymp. Sig. } \\
\text { (2-tailed) }\end{array}$ \\
\cline { 2 - 4 } & $\begin{array}{l}\text { Intervention } \\
\text { Control }\end{array}$ & 19,00 & \\
& Con & 12,00 & 0,029 \\
\hline
\end{tabular}

Based on Table 3 , it is known that the value of Sig. (2-tailed) is $0,020(0,020<0,05)$. Therefore, it could be interpreted that domperidone has a convincing effect toward breast milk production. The score or the value of correlation coefficient is 0,422 . This score is within the correlation strength score $(0,40-0,599)$; it means that the level of correlation strength between domperidone variabke and breast milk variable is modest.

Table 3. Domperidone Effect Test toward Breast Milk Production on Post-SC Mothers between Intervention Group and Control Group

\begin{tabular}{lcc}
\hline & $\begin{array}{c}\text { Correlation } \\
\text { Coefficient }\end{array}$ & Sig.2 Tailed \\
\hline Domperidone & $0,422^{*}$ & 0,020 \\
Breast Milk Production & $0,422^{*}$ & 0,020 \\
\hline
\end{tabular}


The research showed that there is a significant difference between a group of postSC mother who consume domperidone and a group of post-SC mothers who do not cosume domperidone as can be seen in table 1. The pain after SC will choke breast milk production. Beside the infant will be sleepy and less responsive to breastfeed, especially on the mother who consume painkiller before SC (5).

Consuming domperidone is not only effective as prokinetic and antiemetic, but also beneficial to improve breast milk production among nursing mother. On the lactation process hipotalamus releases prolactin-inhibiting hormone $(\mathrm{PIH})$ which is known as neurotransmitter dopamine and prolactin-releasing hormone (PRH). The secretion of both hormones influences the secretion of prolactin. Domperidone works as antagonist receptor of dopamine. The resistance of neurotransmitter dopamine in the brain could suppress to decrease the $\mathrm{PIH}$ production and to increase prolactin hormone. It give positive effect toward the improvement of the secretion of epitel cell alveolar, and stimulate the improvement of breast milk secretion (7).

To value the breast milk production in this research used observation sheet such as the amount of breast milk pumped using electric pump and the consistence of breast, milk that came out from the nipple if it is pressed using hand, the frequency of urinating of the baby 6-8 times a day, sleep/quite after breastfeed, secreting meconium within 24 hours.

The result of this research is in line with a research conducted by Campbell-Yeo, et al (2010), the volume of breast milk consuming domperidon improves up to $26,7 \%$ compared to placebo group that only improves $18,5 \%$ $(p=0,005)$. The signifin=cant improvement of breast milk production statistically after the domperidone treatment is $74,72 \%(95 \% \mathrm{Cl}$ $=54,57 ; 94,86, \mathrm{P}<0,00001)$ in daily breast milk production with domperidone treatment compared to placebo (6).

Then, the table shows that the level of correlation strength between domperidone variabel and breast milk variable is modest or medium; it is in-line with the research by Campbell-Yeo, et al (2010), the volume of breast milk of nursing mother consuming domperidon improve up to $26,7 \%$ compared to placebo group that only improve $18,5 \%(p=0,005)$.

In accordance with research conducted previously that consuming Domperidone $60 \mathrm{mg} /$ day for 14 days improve the breast milk volume as $367 \%$ compared to $30 \mathrm{mg} /$ day that only improves $215 \%(9)$.

There are some factors that cause the breast milk production decreases in the intervention group such as IMD, physical condition of mother/ infant, so room in and breast milk on demand could not be done. A number of researches have stated that Nullipara mother will result in higher prolactin serum compared to multipara in the same dosage of medicine. However, the volume of breast milk produced by multipara is still higher that nullipara (8). The limitation of the research is that the subject of the research is less in number and the researchers did not observe the prolactin serum in every sample being observed.

\section{CONCLUSION AND RECOMENDATIONS}

There is a significant correlation between domperidone variable and breast milk production with the correlation strength level between domperidone and breast milk production is medium. We have to support exclusive breastfeeding by giving motivation, health education, avoiding stress for nursing mother. It is as a consideration to have collaboration to have pharmacological therapy (Domperidon) in order that mother could breastfeed her infant to improve psychological relationship and infant growth. 


\section{REFERENCES}

1. Silawati V, Murnita E. Efektivitas Teh Sibangun bangun Terhadap Volume ASI Pada Ibu Post SC Di Rumah Sakit Marinir Cilandak Tahun 2019. J Qual Women's Heal. 2020;3(2):140-5.

2. Renityas NN. Pengaruh Acupresure terhadap Kecukupan ASI pada Ibu Post Partum SC hari ke 7. J Ners dan Kebidanan (Journal Ners Midwifery). 2020;7(2):293-300.

3. Soedirman JK, Journal TS. Jurnal Keperawatan Soedirman (The Soedirman Journal of Nursing), Volume 5, No.3, Nopember 2010. 2010;5(3):174-81. Available from: http://keperawatan.unsoed. ac.id/sites/default/files/jks20100503_174181.pdf

4. Riskesdas K. Hasil Utama Riset Kesehata Dasar (RISKESDAS). J Phys A Math Theor [Internet]. 2018;44(8):1-200. Available from: http://arxiv.org/abs/1011.1669\%0Ahttp:// dx.doi.org/10.1088/1751-8113/44/8/ 085201\%0Ahttp://stacks.iop.org/1751$8121 / 44 / \mathrm{i}=8 / \mathrm{a}=085201$ ? $\mathrm{key}=$ crossref. abc74c979a75846b3de48a5587bf708f

5. Nurliawati E. Faktor-faktor yang berhubungan dengan produksi air susu ibu pada ibu pasca seksio sesarea di wilayah kota dan kabupaten Tasikmalaya. Jurnak FIK UI. 2010;

6. Osadchy A, Moretti ME, Koren G. Effect of Domperidone on Insufficient Lactation in Puerperal Women: ASystematic Review and Meta-Analysis of Randomized Controlled Trials. Matsui DM, editor. Obstet Gynecol Int [Internet]. 2012;2012:642893. Available from: https://doi.org/10.1155/2012/642893

7. William V, Carrey M, Di D. Domperidone untuk Meningkatkan Produksi Air Susu Ibu ( ASI ). Contin Prof Dev lai. 2016;43(238):225-8.

8. Soto-Pedre E, Newey PJ, Bevan JS, Leese GP. Morbidity and mortality in patients with hyperprolactinaemia: The PROLEARS study. Endocr Connect. 2017;6(8):580-8.

9. Kent JC, Ashton E, Hardwick CM, Rowan MK, Chia ES, Fairclough KA, et al. Nipple pain in breastfeeding mothers: Incidence, causes and treatments. Int $\mathrm{J}$ Environ Res Public Health. 2015;12(10):12247-63.

10. Campbell-Yeo ML, Allen AC, Joseph KS, Ledwidge JM, Caddell K, Allen VM, et al. Effect of domperidone on the composition of preterm human breast milk. Pediatrics. $2010 ; 125(1)$. 